\title{
Chapter 9 \\ Designing Resilient Cities that Work for Women, Too
}

\author{
Jessica L. Barnes
}

\begin{abstract}
Urban landscapes can-and do-influence multiple aspects of our lives, including our overall quality of life and disaster resilience. Research has confirmed that some populations experience negative outcomes in disasters at least partially attributed to poorly designed urban environments; and women's and girls' resilience in particular can be impacted by their experience of the urban landscape. In response, urban designers have an opportunity and an obligation to incorporate gender-sensitive design approaches in all of their projects to ensure the whole community has access to the benefits of urban landscapes. This chapter examines current evidence and strategies for successful urban design that supports resilience in women and the cities they occupy.
\end{abstract}

Keywords Gender mainstreaming • Urban design • Landscape architecture • Inclusive design $\cdot$ Resilient cities

\subsection{Introduction}

Urban landscapes can-and do-influence multiple aspects of our lives, including our overall quality of life (Rondeau et al. 2005; Urban Development Vienna 2013). This observation is what draws me to landscape architecture and urban designthe potential to have large-scale, positive impacts on the people who create our communities and cities. It is only recently, though, that urban designers are starting to understand that these landscapes do not affect everyone equally. Indeed, researchers have confirmed that social, economic, and political factors influence our perceptions of and interactions with the spaces we occupy (Garcia-Ramon et al. 2004), and in some instances, these varied experiences can impact individuals' and communities' disaster resilience (Tidball and Krasny 2013).

I believe that urban designers have an obligation to reduce disaster risk and support resilience in their communities (see also Chap. 12). This is not only because the

\footnotetext{
J. L. Barnes $(\varangle)$

Disaster Resilience Leadership Academy, Tulane University, New Orleans, LA, USA

e-mail: jessi@jessibarnes.com
} 
incidence of disasters is increasing (UNDRR 2019), but also because, as Wisner et al. (2003) put it: “... disasters can be perceived within the broader patterns of society, and ... analyzing them in this way may provide a much more fruitful way of building policies that can help to reduce disasters and mitigate hazards, while at the same time improving living standards and opportunities more generally" (p. 4). In other words, disaster resilience and quality of life are interlinked, and improving one will have a positive impact on the other. This - to me-is the essence of what it means to be an urban designer: improving the quality of life for those in the communities we serve by taking a multifaceted approach to community development that recognizes the role that economic, social, and gender inequalities have in creating truly resilient communities.

When considering disaster resilience and the urban landscape, much has been said about the importance of engineering, infrastructure, and natural systems in protecting communities from physical damage; however, there is less discussion about the importance of connecting the urban landscape to the economic, social, institutional, and community capacities that also make up disaster resilience (Cutter et al. 2010; Tidball and Krasny 2013). Confining the field of urban design to infrastructure and natural systems misses opportunities to build capacities in these interrelated areas.

To expand and build upon the scope of urban design's contribution to disaster resilience, I suggest that designers focus on a near-universally marginalized group of people who routinely experience substandard outcomes in disasters and who account for half of the global population: women and girls. This chapter connects women's disaster resilience to their experiences of and participation in the built environment. To my surprise, while the field of gender and disaster has been well established for some decades (Ashraf and Azad 2015; Enarson and Chakrabarti 2009; Enarson and Morrow 1998a), few studies have specifically examined the intersection between gender, disaster, and the built environment. Likewise, researchers have long-understood that our built environments have various and measurable impacts on our health and well-being (Ekkel and de Vries 2017; Markevych et al. 2017; WHO Regional Office for Europe 2016), but few of these studies have gender dis-aggregated their data or connected it to resilience. With this in mind, I'd like to spark a conversation between researchers, design professionals, and women and their communities to consider the myriad of potential benefits of combining efforts. As I will demonstrate, bringing these stakeholders together to design and build our cities has the potential to proactively support resilience among over half of our world's human population and will likely have positive outcomes for the other half as well.

Why focus on women's disaster resilience? As Wisner et al. (2003) observe in At Risk: Natural Hazards, People's Vulnerability, and Disasters, "gender is a pervasive division affecting all societies, and it channels access to social and economic resources away from women and towards men" (p. 48). Enarson and Chakrabarti (2009) assert that gender must be a mandatory, critical dimension of all initiatives in order to create more sustainable societies. To understand how urban landscapes affect communities differently, city officials must identify which stakeholders have the most limited voices when it comes to making decisions about the built environment. Since men overwhelmingly dominate the field of urban planning and design 
(Rustin 2014; The American Institute of Architects 2015), women represent a prime target demographic for this purpose. In short, our urban landscapes have a male bias - a bias that must be addressed and corrected to improve a community's overall disaster resilience.

In this chapter, I review both published articles and gray literature that document gender-specific outcomes for women and girls in disasters. I compare these studies to research concerning the measurable impacts that the built environment can have on individual and community capacities while looking for overlap and commonalities between the two fields. Finally, I speculate on how these connections between urban design and disaster resilience might influence the future of the design of the built environment and how the lessons gleaned so far might have a broader impact on resilience.

\subsection{Definitions}

Discussing women and girls as a homogeneous demographic group disguises the rich diversity among them. Women as individuals will all have unique and valuable skills, knowledge, and experiences that can contribute to building more resilient cities (Hankivsky 2005). While I note specific demographics of women when such information is available, generally I use the term with broad strokes. In this paper, "women" refers to people of all ages who were born female, people who identify as women, and/or people who perform labor traditionally assigned to women, like caregiving and domestic work. Each broad group of women may overlap, and some might include men. Perhaps because of this diversity, cities designed with and for women have the potential to benefit the community across many demographics (Micklow et al. 2015; Women in Cities International 2010).

When discussing women's disaster resilience, I'm referring to resources that support an individual's and a community's capacity to respond to and recover from a hazard. Capacity relates to five major areas of resilience: social resilience, economic resilience, infrastructure resilience, institutional resilience, and social capital (Cutter et al. 2010). Vulnerability, on the other hand, describes those barriers that limit an individual's or a community's ability to respond to disasters. Importantly, all communities have both vulnerability and resilience.

Gender mainstreaming, also called gender-based analysis, means normalizing decision making to consider how any planned decision, policy, or program might impact both women and men (Bellitto 2015). It is considered the most favored strategy for gender inclusion among urban design professionals around the world (Hankivsky 2005). Though often associated more strongly with women, gender mainstreaming emphasizes that women's and men's needs are equally important and must equally be accounted for when making decisions (Bellitto 2015).

As already discussed, considering gender alone has the potential to be too broad, missing valuable opportunities and feedback. Hankivsky (2005) argues that one of the main weaknesses of gender mainstreaming is that it creates a dichotomy of 
male versus female at the expense of embracing intersectionality. She advocates for highlighting the relationships among gender, class, sexuality, race, ethnicity, and power (Hankivsky 2005). I acknowledge that gender mainstreaming, as compared to diversity management, has the potential to exclude marginalized populations. However, scholars like Bellitto (2015) believe that gender mainstreaming might be the most acceptable entry point to challenging the status quo in countries, such as the USA, that lag behind in achieving gender equality, since it can be implemented from both the top-down and bottom-up. Future studies should compare the results of gender and diversity mainstreaming within urban design to determine a framework that could have the most positive impact.

Following the precedent set in Urban Green Spaces and Health: A Review of Evidence (WHO Regional Office for Europe 2016), I choose to approach the definition of the urban landscape in a holistic way. Perhaps most obviously, these terms describe the physical environments that cities occupy. This includes green spaces like parks, plazas, and nature preserves; natural features like rivers, forests, and air quality; and transportation networks like bike lanes, bus routes, and streets (WHO Regional Office for Europe 2016). Urban landscape also describes policies that direct how the physical environment takes form, for example: zoning policy, planning regulations, and design guidelines for new development (Micklow and Warner 2014). The various components of the urban landscape combine to create the overall experience of being in the city.

\subsection{Women, Girls, and Disaster}

The influence of gender on disaster resilience is well-documented, and it should come as no surprise that women and girls are often more marginalized and vulnerable to disaster compared to men (Ashraf and Azad 2015; Criado Perez 2019; Enarson and Chakrabarti 2009). For example, women are more likely to be affected by a disaster, and they're more likely to die or experience trauma during a disaster (O'Reilly et al. 2015). Tragically, they also experience increased rates of male violence after a disaster (Wilson et al. 1998). Women's needs are less likely to be accounted for during disaster. For example, on more than one occasion, homes rebuilt after disasters lacked kitchens (Criado Perez 2019, p. 290), and stories of shortages of menstruation and breastfeeding-related supplies in post-disaster shelters and temporary housing abound (Criado Perez 2019; Hargest-Slade and Gribble 2015). Facilities to support common income-generating opportunities, like small-scale markets and childcare, go ignored and unbuilt (Enarson and Morrow 1998b). Given these realities and the fact that women and girls represent half of everybody, a logical question to ask is: Why is this happening?

Ariyabandu (2009) says that women's vulnerability to disaster springs from preexisting gender relations, which create differences in social and economic status, mortality rates, needs, gender-based prejudices, among other disparities. Criado Perez (2019) takes a simpler approach, distilling the reasons for women's inequal 
status as being related to "the female body, women's unpaid care burden, and male violence against women" (p. 49). Cannon (2002) argues that vulnerability depends on "initial conditions" like a person's health, mobility, and capacity for self-reliance. In all accounts, the circumstances that contribute to better or worse outcomes are created in our daily lives, prior to disaster. What do we know about women's existing conditions that improve or detract from their disaster resilience, and how might those conditions relate to the built environment? To answer this question, I have identified four areas of inquiry: women's transportation and economic resilience, access to safe public spaces, women's specific health needs, and inclusion and leadership through gender mainstreaming.

\subsection{Transportation and Economic Resilience}

Economic capacity often represents the most significant predictor of a person's resilience and ability to recover after a disaster (Ashraf and Azad 2015; Cutter et al. 2010), and women tend to start off in a worse economic position than men when a disaster strikes. In 2007, 23.8\% of American women heads-of-household were in poverty (English et al. 2009). Single, working women headed one-fifth of all households with children, and they were nearly twice as likely to be unemployed as married men, possibly because of the challenge of finding work and childcare whose schedules and locations often do not complement each other (English et al. 2009). Even for those working, employment does not necessarily guarantee equitable economic opportunities. Hegewisch and Williams-Baron (2018) documented that women continue to work in female-dominated occupations, which have lower salaries on average than male-dominated occupations at similar skill levels. When women's salaries are compared to men's salaries within the same female-dominated occupations, men still out-earn women (Hegewisch and Williams-Baron 2018). Consider this: In the USA, for every one man with poverty-level wages, there are eight women also in poverty (Hegewisch and Williams-Baron 2018). With fewer and more marginalized economic opportunities, strengthening access to women's economic resources has the potential to significantly improve resilience.

Reliable transportation provides the foundation for accessing many urban resources, including economic resources, and is directly connected to women's resilience. So, struggling with limited mobility can compromise resilience due to less access to jobs and careers, professional development, economic status, and personal well-being and health (Loukaitou-Sideris et al. 2009; Madariaga 2013a). And women do struggle. Despite the fact that on average more women than men rely on public transportation in their daily lives, the design of many public transportation routes and schedules typically frustrate women (Action Aid International 2013; LoukaitouSideris et al. 2009; Madariaga 2013a). Their frustration stems from the fact that women and men have vastly different travel patterns, but transportation systems tend to prioritize commuter travel needs, which traditionally favor men (Micklow et al. 2015). Since women continue to shoulder the majority of unpaid care-giving and 
household work, commuter-centric design further puts women at a disadvantage (Khazan 2016; Madariaga 2013a). People who are responsible for care-giving and domestic work are more likely to trip-chain, a pattern of mobility characterized by connecting multiple trips into one outing (Micklow and Warner 2014). For example, a woman might drop her children off at school, go to work, leave work, pick up her kids, go grocery shopping, and check-in on an elderly parent before finally returning home at the end of her day. If the same woman relies on public transportation, a disproportionate amount of her day will be spent in transit (Micklow et al. 2015). That is in addition to the extra unpaid hours she will spend on domestic duties like child and elder care and housework, which women are more likely to be responsible for around the world (OECD 2014). While urban design is limited in its influence on the division of care-giving and household work, it has a tremendous impact on transportation options.

Even though women use public transportation more frequently than men, transportation systems have historically been designed for the commuter at the expense of the caregiver; that is, transportation design tends to focus on single-trip journeys between home and work or school (Madariaga 2013a). One reason for this is how transportation planners evaluate travel needs. Conventionally, transportation planners categorize trips into "essential" and "non-essential" groups; however, many trips that get labeled as "non-essential" are related to essential care-giving activities like grocery shopping and escorting children to school (Madariaga 2013a). When care-giving activities are grouped together, they account for about a third of all trips taken, hardly "non-essential" (Madariaga 2013a). Other mobility differences include: women tend to have less access to cars, cease driving earlier than men as they age, make more multi-modal trips, and their trips tend to be "shaped as polygons" (as opposed to the straight, two point travel associated with men) which often requires catching connecting trains or buses to get where they need to go (Madariaga 2013a; Micklow et al. 2015). Basically, women's mobility patterns are more complex than men's, but the urban landscape and transportation systems often aren't designed with women's needs in mind (Madariaga 2013a; Perera 2008).

As will be discussed more later in this chapter, safety concerns keep many women from accessing public spaces or walking alone on the street, and this includes public transportation. If the public felt more secure, public transportation ridership in the UK would increase $10.5 \%$ according to the UK Department of Transport (LoukaitouSideris et al. 2009). When asked how to improve their sense of safety while traveling, women often identify poor lighting as a top concern (Johnson and Miles 2014). Urban design professionals often seek to improve lighting in public places, especially on streets and around station platforms or bus stops, as an initial design intervention (Johnson and Miles 2014). However, this strategy works only when areas surrounding these transit hubs, like parking lots, are also well-lit to avoid a "fishbowl" effect (Loukaitou-Sideris et al. 2009). Additionally, women have pointed out that wellmaintained, clean areas that are free of graffiti and debris feel safer than poorly maintained spaces (Loukaitou-Sideris et al. 2009).

Loukaitou-Sideris et al. (2009), who performed a comprehensive review of literature concerning safety and transit and surveyed 16 representatives of women's interest 
groups on the topic, found that women's and men's preferences in safety interventions for public transportation differed. Women clearly favored more visible interventions like additional security staff in public places compared to technological interventions like CCTV, which men preferred (Loukaitou-Sideris et al. 2009). Women also feel safer with clear sightlines and no corners or tight spaces where someone could hide (Loukaitou-Sideris et al. 2009). In contrast, a concurrent survey of 245 transit authorities in the USA revealed that transportation agencies are choosing the opposite of what women want, with a clear preference for technology (Loukaitou-Sideris et al. 2009). More puzzling, most of the transportation agencies that responded to the survey did not employ security officers nor have a desire to. In contrast, transportation agencies that do provide officers stationed at their facilities reported that they are "very effective and [give] you a nice, secure feeling" (Loukaitou-Sideris et al. 2009).

Improving access to transportation elevates community-especially women'sresilience by improving access to economic capital through more time available for jobs, study, and networking (Cutter et al. 2010). Urban design professionals need to create user-friendly, safe transportation systems that accommodate multiple transportation styles and patterns, paying specific attention to improving options for women.

\subsection{Access to Safe Public Spaces}

Transportation areas aren't the only public spaces that need to be made safer. On a global scale, violence against women remains a dire crisis, not just for women themselves, but for society as a whole, as it limits the full participation of half of the population in public life (Johnson and Miles 2014). In addition to this violence, women experience sexual harassment on a near-universal scale. A recent study from the nonprofit organization Stop Street Harassment found that $81 \%$ of women and $43 \%$ of men report experiencing some form of sexual harassment or assault at some point in their lives (Kearl 2018). Worse, official crime statistics do not represent the full scope of sexual crimes against women. A survey in New York City found that 96 percent of victims of harassment did not file a report with the police or the transportation agency (Stringer 2007). On an extreme, sexual violence has been explicitly used to prevent women from occupying public spaces. A study in Egypt found that some groups deliberately dispatched men to rape and molest women taking part in the 2013 Tahrir Square protests in Cairo (Langohr 2013). Tandogan and Ilhan (2016) speculated that because of these realities, when women discuss their fear in public spaces, what they are really discussing is women's fear of sexual violence in public spaces. Sexual violence, overt harassment, and crass remarks all create a hostile urban environment for many women (Tandogan and Ilhan 2016).

This information is important to contextualize broader statistics on violence in public places. While women are more likely to report violence in private spaces, it is men — not women — who are more likely to be victims of violence and crime in public 
(Rollnick 2007). Despite that, women are more likely to feel unsafe in public spacetwo to three times as afraid by some estimates (Reid and Konrad 2004). Therefore, while men are more likely to be in danger, women are more likely to be aware of danger (Loukaitou-Sideris et al. 2009). In addition to encouraging women's use of the urban landscape, women's insights on public safety have the potential to reduce crimes against men as well since safer places will be safer for everyone (Micklow et al. 2015).

Further complicating the issue, Loukaitou-Sideris et al. (2009) found in a survey of US women that culture plays a significant role in propagating women's fear. As one interviewee observed, "[the societal dialog] has done a very good job of convincing women that [they] are unsafe in public space" (Loukaitou-Sideris et al. 2009). Parents have been found to have stricter rules for their daughters concerning curfews and mobility compared to their sons, possibly because of disproportionate media attention given to crimes against women (Loukaitou-Sideris et al. 2009). We teach our girls to believe they're vulnerable in public places, even though our boys might benefit more from the warning.

Therefore, it's not surprising that Loukaitou-Sideris et al. (2009) concluded that fear of crime is a primary barrier to women's access to the urban landscape, while Madariaga (2013b) connected the fear of public spaces to the fear of public transportation, which I've already discussed. This perceived danger-whether immediate or not - causes many women to self-limit their movements (Women 2017). Women might be reluctant to be in public space at certain hours or avoid a place altogether (Madariaga 2013a). Many women who steer clear of plazas or parks might be reducing their chances for serendipitous encounters that could build their social networks (Johnson and Miles 2014); avoiding travel at certain times of day might limit economic opportunities (Halsall 2001); spending less time walking outside could compromise health (Frank et al. 2008); and limiting use of public space might reduce women's voices in public discussions (Perera 2008). Because unsafe environments limit access to urban landscapes' wide array of resources, it is reasonable to identify a lack of safety as a key vulnerability in the urban landscape that affects women in particular. Urban design professionals must recognize that improving safety is an opportunity to support resilience, especially for women.

How can urban design professionals take these considerations into account when designing the urban landscape? The obvious answer is to ask women what they need and what they're lacking (Criado Perez 2019). For example, Toronto's Metropolitan Action Committee on Violence Against Women and Children developed the Women's Safety Audit tool for this purpose. It allows cities to undertake a critical evaluation of their built environment and has since become the most widely used tool to assess urban safety around the world (Rollnick 2007; Women in Cities International 2008). In these audits, women document specific features that either increase or decrease their sense of safety in places that they frequently visit, like bus stops and train stations (Lambrick et al. 2011). Other popular tools include focus group discussions and street surveys (Lambrick et al. 2011).

A word of caution: In documenting women's needs, urban design professionals must self-screen for benevolent sexism in their actions and words. Benevolent sexism 
is the well-intentioned actions or words based on inherent gendered stereotypes (Meagher Benjamin 2017); cities must avoid the "damsel in distress" rhetoric and instead encourage women to take the lead in designing their own safety measures (Rogers 2014). This is especially vital when considering controversial interventions like creating female-only spaces. In addressing safety concerns on public transportation, some trains and buses in Japan, Mexico, Germany, and Thailand have designated women-only areas, and many cities are implementing rideshares and common spaces like gyms and apartment buildings that are just for women (Hillin 2016). Train companies in Tokyo documented a $3 \%$ reduction in the number of reported cases of lewd behavior after designating cars for women, so these programs appear to offer some success in reducing harassment ("Japanese women can now travel in women-only train cars to avoid groping," 2006). Similarly, Germany, China, and Switzerland have all experimented with designated parking spots for women that place them closer to their destinations (Hillin 2016). However, despite the growing popularity of female-only spaces, some scholars and activists reject segregation as a solution to improving women's safety, advocating that the onus is on men to treat women with respect, not on women to evade men (Hillin 2016). Local women need to decide which approaches suit them, and the answers will vary across communities.

Fear of crime affects more than just access to public spaces; it takes a toll on women's health as well. Stafford et al (2007) found that people who are afraid of crime showed lower levels of mental health, exercised less, and had an overall reduced quality of life. They participated in fewer social activities and saw their friends less frequently (Stafford et al. 2007), so improving public safety will likely improve women's health as well.

\subsection{Women's Specific Health Needs}

A 2012 meta-analysis of men and women across 57 countries showed that women report significantly lower health than men, and this held true across different ages, socioeconomic statuses, and countries (Hosseinpoor et al. 2012). The U.S. Centers for Disease Control and Prevention estimates that illness and injury cost the economy $\$ 225.8$ billion annually (CDC Foundation 2015). Poor health can also result in personal financial burdens because of missed work (Gould and Schieder 2017). Similar to how women lose time navigating lousy transportation systems, time lost to illness robs time from other activities that could benefit resilience. Chronic health concerns can negatively impact a person's overall quality of life (Ekkel and de Vries 2017). Since women manage poor health more often than men, improving health outcomes can directly contribute to women's resilience. So where do urban designers fit in?

One community-wide approach to improving health is to increase access to green space (Markevych et al. 2017; Wood et al. 2017). A recent report from the World Health Organization Regional Office for Europe (2016) summarized decades of studies that examined the relationships between urban green space and health, 
affirming that the available evidence supports the observation that increased exposure to green space correlates to better health and wellness. In particular, green space most significantly affects mental health compared to other aspects of health that have been studied (WHO Regional Office for Europe 2016).

While it remains unclear precisely which aspects of green space influence health, the WHO Regional Office for Europe identified nine possible pathways in which these benefits might be realized (Table 9.1). While it is possible that green spaces can contribute to some negative health impacts, it appears that the benefits of green space outweigh the negatives (WHO Regional Office for Europe 2016). Likewise, the authors note that many of these adverse effects can be mitigated with design and best practices in maintenance; for example, maintenance crews might use only the minimum amount of pesticides and herbicides, which would reduce or eliminate the risk of exposure (WHO Regional Office for Europe 2016).

From a women-exclusive perspective, studies have connected green space to improved reproductive health outcomes in pregnant women. They have found that proximity to green space predicted reduced blood pressure (Grazuleviciene et al. 2014), lower rates of depression (McEachan et al. 2016), and tendency to have children with higher birth weights (Dzhambov et al. 2014). Similarly, a Lithuanian study found that the risk of preterm birth and younger gestational age decreased as the

Table 9.1 Summary of findings from Urban green spaces and health: A review of evidence (WHO Regional Office for Europe 2016)

\begin{tabular}{l|l|l}
\hline Pathways to improved health & $\begin{array}{l}\text { Positive effects of urban green } \\
\text { space }\end{array}$ & $\begin{array}{l}\text { Negative effects of urban } \\
\text { green space }\end{array}$ \\
\hline $\begin{array}{l}\text { Improved relaxation and } \\
\text { restoration }\end{array}$ & $\begin{array}{l}\text { Improved mental health and } \\
\text { cognitive function }\end{array}$ & Risk of allergies and asthma \\
\hline Improved social capital & $\begin{array}{l}\text { Reduced cardiovascular } \\
\text { morbidity }\end{array}$ & $\begin{array}{l}\text { Exposure to pesticides and } \\
\text { herbicides }\end{array}$ \\
\hline $\begin{array}{l}\text { Improved functioning of the } \\
\text { immune system }\end{array}$ & $\begin{array}{l}\text { Reduced prevalence of Type } \\
\text { II diabetes }\end{array}$ & $\begin{array}{l}\text { Exposure to disease vectors } \\
\text { and zoonotic infections }\end{array}$ \\
\hline $\begin{array}{l}\text { Enhanced physical activity, } \\
\text { improved fitness, and reduced } \\
\text { obesity }\end{array}$ & $\begin{array}{l}\text { Improved pregnancy } \\
\text { outcomes }\end{array}$ & Accidental injuries \\
\hline $\begin{array}{l}\text { Anthropogenic noise buffering } \\
\text { and production of natural } \\
\text { sounds }\end{array}$ & Reduced mortality & $\begin{array}{l}\text { Excessive exposure to UV } \\
\text { radiation }\end{array}$ \\
\hline $\begin{array}{l}\text { Reduced exposure to air } \\
\text { pollution }\end{array}$ & & \\
\hline $\begin{array}{l}\text { Reduction of the urban heat } \\
\text { island effect }\end{array}$ & & \\
\hline $\begin{array}{l}\text { Enhanced pro-environmental } \\
\text { behavior }\end{array}$ & & \\
\hline $\begin{array}{l}\text { Optimized exposure to sunlight } \\
\text { and improved sleep }\end{array}$ & & \\
\hline
\end{tabular}


distance between residences and city parks decreased (Grazuleviciene et al. 2015). Women uniquely benefit in other ways from green space. A cross-sectional study of four European cities found that all participants who spent more time in green space reported fewer symptoms of anxiety, but only women reported significantly fewer symptoms of depression (van den Berg et al. 2016). Meanwhile, von den Bosch et al. (2015) found that serene landscapes - described as safe, calm environments_-predicted significantly reduced mental health illnesses in women, supporting similar findings from Annerstedt et al. (2012). Kuo and Sullivan (2001) found in a study of inner city urban public housing residents that women whose homes were near nature were significantly less likely to report aggressive or violent behavior. A study of disadvantaged neighborhoods in Detroit, Michigan, found that people living in neighborhoods with strong local street networks and connections to the surrounding urban area reported higher levels of walking (Wineman et al. 2014); however, the authors of this study did not present gender dis-aggregated data. In contrast, a cross-sectional review of people in Atlanta showed that men tended to be thinner as connectedness increased, while women tended to be heavier (Frank et al. 2008). Frank et al. (2008) speculate that this could be related to women's perceptions of safety and use of public space. As already discussed, if women are fearful for their safety, they are less likely to walk outside. Though the authors did not address it, another possibility is that the street networks fail to address women's needs, perhaps by lacking adequate sidewalks that people with strollers, children, or mobility impairments can easily navigate (Loukaitou-Sideris et al. 2009).

Various qualities and types of green space have been shown to have different health impacts. Work by Akpinar et al. (2016) indicates that the type of green space influences its overall effect. In their analysis, they found that access to forests and urban green spaces reduced mental health complaints in Washington State more than compared to access to wetlands, rangeland, or agricultural land. Goto et al. (2017) evaluated the cognitive health impacts of experiencing Japanese-style garden design, finding that cognition and relaxation improved in patients with dementia and Alzheimer's disease when exposed to a Japanese-style garden compared to an "unstructured" garden. The team had previously found that elderly, cognitively intact individuals experienced less stress and improved overall mood when exposed to Japanese-style gardens (Goto et al. 2013).

Partly because of its correlation to mental health, green space has been found to aid in healing after disasters as well. Okvat and Zautra (2013) assert that community gardening and exposure to gardens has the potential to build resilience after a disaster. They use Common Ground Relief in New Orleans, Louisiana, as an example. Common Ground Relief is a nonprofit organization created after Hurricane Katrina to aid and assist community members in creating their own urban and community gardens, an effort that Okvat and Zautra describe as providing exercise and respite. Also in New Orleans, produce from community gardens in the local Vietnamese communities helped the neighborhood come back sooner, before grocery stores were open (Okvat and Zautra 2013). Meanwhile, Krasny et al. (2013) make the case for using nature exposure to help returning military veterans build their 
resilience and readjust to home life. They point to the growing popularity of horticulture therapy, employing veterans in green jobs, or encouraging them to become involved in gardening, hunting, fishing, and other outdoor activities. These examples of green space providing restorative effects to people who were traumatized in disasters are a new field of research with few studies and even fewer with gender dis-aggregated data, so more work needs to be done to learn how to tailor healing nature-based programs to different demographics in after-disaster contexts.

\subsection{Inclusion and Leadership Through Gender Mainstreaming}

We've examined the influence of transportation-, safety-, and health-related aspects of the built environment that impact women's resilience. At this point, you might be asking yourself why these inequalities continue to persist in our communities? The short answer is there has been a toxic and fundamental lack of representation of women in leadership and decision-making roles.

Why should urban design and emergency management professionals recruit more women when planning to improve their community's disaster resilience? For starters, diversity in leadership leads to more innovation, which has the potential to make communities more flexible and adaptable (Lorenzo and Reeves 2018), and if one thing is certain, it's that there is a dearth of women in the urban design world. Women are terribly underrepresented in the urban design professions, and the situation is especially bleak when examining leadership and professional roles (Rustin 2014; The American Institute of Architects 2015). Additionally, women in the community are less likely to have their voices heard in public meetings or in public design forums (Micklow et al. 2015). With decision-makers skewed heavily male, it is not surprising that an increasing body of research has documented widespread bias against women in the urban landscape (Greed 1996; Micklow et al. 2015; Urban Development Vienna 2013).

The USA is one of only seven U.N. member nations that hasn't ratified the U.N.'s Convention to Eliminate All Forms of Discrimination Against Women (Bellitto 2015), and the USA ranks 49th in the U.N.'s 2017 Global Gender Gap Report (World Economic Forum 2017). Clearly, there is plenty of room for improvement. That said, some regions - particularly Europe, Canada, and Australia-lead by example with decades of gender mainstreaming under their belts (Bacchi et al. 2010). Some of these communities have already started the transition to more-inclusive, diversity mainstreaming policies, also called diversity management (Executive Group for Organisation, Safety and Security 2011).

Male bias in the urban landscape is the tendency for cities to cater to men's needs while neglecting or sidelining women's and minority's needs (Garcia-Ramon et al. 2004). Male bias is rarely malicious; it's more a product of men in power forgetting about (and therefore missing out on) women's knowledge and capabilities (Criado 
Perez 2019). Bias, at its heart, stems from a lack of female and minority representation in urban planning, city government, and community design—especially in leadership and decision-making roles (Enarson and Morrow 1998a). This lack of representation creates a blind spot for urban design professionals, and it hinders cities' ability to respond to and benefit from women's and minority's perspectives, wisdom, and insights, which are too often absent from public discussion (Greed 2007; Sham et al. 2013; Women 2017; Women in Cities International 2010). As an example of that blind spot, a survey of 624 planners in the USA found that just $2 \%$ of comprehensive plans addressed women's needs specifically, and only $7 \%$ of respondents agreed with the statement "developers are responsive to the special needs of women" (Micklow et al. 2015). The American Institute of Architects (2015) found in a 2014 survey that while women agreed that the industry had not yet achieved gender equality, only half of men surveyed held the same perspective. This implies that half of the men at the table do not recognize the gendered bias against women in their field. This does not bode well for improving representation in the USA in the near future. Simply put, women's voices aren't being heard. Without an awareness of women's needs, how can cities possibly respond to them?

Urban design professionals increasingly look to gender mainstreaming as one avenue for including women and countering male bias (Bacchi et al. 2010). Since the strategy prioritizes both women and men, gender mainstreaming actively addresses the needs of all stakeholders. The importance of direct engagement with a community's women cannot be overstated. Women have different needs globally and within the same city (Loukaitou-Sideris et al. 2009; Urban Development Vienna 2013). It's impossible to predict these needs without gender mainstreaming. Unsurprisingly, there are very few examples of gender mainstreaming in the USA (Abbey-Lambertz 2016), but that also means there's ample opportunity for improvement.

Gender mainstreaming requires a comprehensive approach to be effective (Executive Group for Organisation, Safety and Security 2011; Urban Development Vienna 2013). Praised for its inclusive process in urban planning and governance, Vienna has been actively gender mainstreaming since the early 1990s (Bellitto 2015). Their model includes guidelines for gender-inclusive language on public documents, demographically diverse decision-making teams, and analysis of gendered impacts of city budgets and projects (Executive Group for Organisation, Safety and Security 2011). In their early mainstreaming efforts, women expressed concerns about their access to transportation (Executive Group for Organisation, Safety and Security 2011). By including women and asking them for insights, Vienna has been able to improve women's access to transportation through neighborhood-centric bus routes, lifts for patrons who struggle with stairs, like a person pushing a stroller, and improved lighting across the system (Criado Perez 2019). Vienna's women identified other gaps where public spaces weren't working for them-from parks to housing developments, women's voices have changed the way that Vienna is designed (Foran 2013). In recognition of its success, the program received the United Nations Human Settlements Programme Excellence in Urban Planning award in 2010 (Hassan 2010), and it still shines as a leading example of gender mainstreaming the urban landscape. 
Listening to women's needs by including them into urban design processes can promote equitable access to urban landscapes. This was evident in the Nou Barris neighborhood in Barcelona where Garcia-Ramon et al. (2004) documented the transformation of Via Julia, which was accomplished with strong leadership from women. As part of the participatory process in seeking public input for the redesign, women asserted their needs for "street lights, pedestrian paths, lighting, etc." (Garcia-Ramon et al. 2004, p. 219). They demanded integrated spaces for shops, playgrounds, seating areas, and safe access to public transportation (Garcia-Ramon et al. 2004). As a result of taking women's needs into account, Garcia-Ramon, Ortiz, and Prats documented nearly balanced use between men and women of the redesigned public boulevard. They found that different demographic groups tended to filter in and out of the boulevard with time of day according to traditional schedules (Garcia-Ramon et al. 2004). The researchers conclude that the success of the space came, in part, because it was designed in negotiation with the whole community, including women, which allowed for diverse groups of people within the neighborhood to appropriate the space as their own and for their own uses.

\subsection{Moving Forward}

Urban landscapes contribute to and influence disaster resilience. Moreover, since everyone's personal knowledge, experiences, and skills inform their perceptions of and relationship to the urban landscape, the landscape can affect resilience in different ways among different people. Since men have been the primary shapers of the urban environment, women's needs have often been neglected in the design of their cities. Urban design professionals can use gender mainstreaming to equalize the landscape, build women's capacities across the spectrum of resilience, and increase their city's overall disaster resilience in the process. Transportation, safe access to public space, and health can all be improved through thoughtful, inclusive urban design, implying that investment in these areas could have broad effects in improving disaster resilience.

While this chapter has identified broad areas for design interventions that have the potential to improve overall resilience, cities must implement their own engagement programs to find their community's individual and unique approaches to gendering their urban landscapes and improving their disaster resilience. Administrators and leaders must commit to supporting the education and recruitment of women urban planners, landscape architects, architects, and engineers (Fleming and Tranovich 2016). They should look to global leaders in gender mainstreaming for inspiration and direction; for example, they could consult Vienna's Gender Mainstreaming Made Easy: Practical Advice for More Gender Equality in the Vienna City Administration (Executive Group for Organisation, Safety and Security 2011) for detailed and practical steps that cities can take to begin their journey toward gender equity. Urban design professionals should strive to collect preliminary data on their city's resilience and their city's current gender equity in order to monitor progress and 
to look for correlations between gendered urban landscapes and resilience that are working in their communities. Cities should emphasize that gender mainstreaming is every department's responsibility while also appointing a specific task force or gender mainstreaming officer to ensure that someone is responsible for monitoring and developing the program (Bacchi et al. 2010).

The urban landscape's role in supporting all aspects of disaster resilience is still poorly understood, and even less so when considering how it supports various demographic groups differently, but the preliminary data are promising. As urban design professionals and researchers expand the knowledge around these topics, they will find many more opportunities to maximize investments into the urban landscape so that they respond to all community members' needs and grow resilience.

\section{References}

Abbey-Lambertz, K. (2016, April 26). Cities Aren't Designed For Women. Here's Why They Should Be. Huffington Post. Retrieved from https://www.huffingtonpost.com/entry/cities-designed-forwomen_us_571a0cdfe4b0d0042da8d264.

Action Aid International. (2013). Women and the City II: COMBATING VIOLENCE AGAINST WOMEN AND GIRLS IN URBAN PUBLIC SPACES - THE ROLE OF PUBLIC SERVICES.

Akpinar, A., Barbosa-Leiker, C., \& Brooks, K. R. (2016). Does green space matter? Exploring relationships between green space type and health indicators. Urban Forestry \& Urban Greening, 20, 407-418. https://doi.org/10.1016/j.ufug.2016.10.013.

Annerstedt, M., Östergren, P.-O., Björk, J., Grahn, P., Skärbäck, E., \& Währborg, P. (2012). Green qualities in the neighbourhood and mental health - results from a longitudinal cohort study in Southern Sweden. BMC Public Health, 12, 337. https://doi.org/10.1186/1471-2458-12-337.

Annerstedt van den Bosch, M., Östergren, P.-O., Grahn, P., Skärbäck, E., \& Währborg, P. (2015). Moving to Serene Nature May Prevent Poor Mental Health-Results from a Swedish Longitudinal Cohort Study. International Journal of Environmental Research and Public Health, 12(7), 79747989. https://doi.org/10.3390/ijerph120707974.

Ariyabandu, M. M. (2009). Sex, gender and gender relations in disaster. In Elaine Enarson \& P. G. D. Chakrabarti (Eds.), Women, Gender, and Disaster. New Delhi: SAGE Publications.

Ashraf, M. A., \& Azad, Md. A. K. (2015). Gender Issues in Disaster: Understanding the Relationships of Vulnerability, Preparedness and Capacity. Environment and Ecology Research, 3(5), 136-142. https://doi.org/10.13189/eer.2015.030504.

Bacchi, C., Eveline, J., Binns, J., Mackenzie, C., \& Harwood, S. (2010). Gender analysis and social change: testing the water. In Mainstreaming Politics: Gendering Practices and Feminist Theory (pp. 61-85). University of Adelaide Press.

Bellitto, M. (2015). Gender mainstreaming in the United States: a new vision of equality. 22(2), $125-150$.

Cannon, T. (2002). Gender and climate hazards in Bangladesh. Gender and Development, 10(2), $45-55$.

CDC Foundation. (2015, January 28). Worker Illness and Injury Costs U.S. Employers $\$ 225.8$ Billion Annually. Retrieved April 15, 2018, from CDC Foundation website: https://www.cdcfou ndation.org/pr/2015/worker-illness-and-injury-costs-us-employers-225-billion-annually.

Criado Perez, C. (2019). Invisible Women: Data Bias in a World Designed for Men. New York: Abrams Press. 
Cutter, S. L., Burton, C. G., \& Emrich, C. T. (2010). Disaster Resilience Indicators for Benchmarking Baseline Conditions. Journal of Homeland Security and Emergency Management, 7(1). https:// doi.org/10.2202/1547-7355.1732.

Dzhambov, A. M., Dimitrova, D. D., \& Dimitrakova, E. D. (2014). Association between residential greenness and birth weight: Systematic review and meta-analysis. Urban Forestry \& Urban Greening, 13(4), 621-629. https://doi.org/10.1016/j.ufug.2014.09.004.

Ekkel, E. D., \& de Vries, S. (2017). Nearby green space and human health: Evaluating accessibility metrics. Landscape and Urban Planning, 157, 214-220. https://doi.org/10.1016/j.landurbplan. 2016.06.008.

Enarson, E., \& Chakrabarti, P. G. D. (2009). Women, Gender and Disaster: Global Issues and Initiatives (1st ed.). Thousand Oaks, California: SAGE Publications.

Enarson, E., \& Morrow, B. H. (1998a). Why Gender? Why Women? An Introduction to Women in Disaster. In The Gendered Terrain of Disaster: Through Women's Eyes. (pp. 1-10). Westport, Connecticut: Praeger Publishers.

Enarson, E., \& Morrow, B. H. (1998b). Women Will Rebuild Miami: A Case Study of Feminist Response to Disaster. In The Gendered Terrain of Disaster: Through Women's Eyes (p. 275). Westport, Connecticut: Praeger Publishers.

English, A., Hartmann, H., \& Hegewisch, A. (2009). Unemployment Among Single Mother Families (No. C369; p. 4). Institute for Women's Policy Research.

Executive Group for Organisation, Safety and Security. (2011). Gender Mainstreaming Made Easy: Practical Advice for More Gender Equality in the Vienna City Administration (pp. 46-46). Vienna: City of Vienna.

Fleming, Rew, \& Tranovich, A. (2016, October 13). Why aren't we designing cities that work for women, not just men? Retrieved April 3, 2018, from the Guardian website: https://www.theguardian.com/global-development-professionals-network/2016/oct/13/ why-arent-we-designing-cities-that-work-for-women-not-just-men.

Foran, C. (2013, September 13). How to Design a City for Women. Retrieved March 30, 2018, from CityLab website: https://www.theatlanticcities.com/commute/2013/09/how-design-city-women/ $6739 \%$.

Frank, L. D., Kerr, J., Sallis, J. F., Miles, R., \& Chapman, J. (2008). A hierarchy of sociodemographic and environmental correlates of walking and obesity. Preventive Medicine, 47(2), 172-178. https://doi.org/10.1016/j.ypmed.2008.04.004

Garcia-Ramon, M. D., Ortiz, A., \& Prats, M. (2004). Urban planning, gender and the use of public space in a peripherial neighbourhood of Barcelona. Cities, 21(3), 215-223.

Goto, S., Bum-Jin Park, Tsunetsugu, Y., Herrup, K., \& Miyazaki, Y. (2013). The Effect of Garden Designs on Mood and Heart Output in Older Adults Residing in an Assisted Living Facility. Health Environments Research \& Design Journal (HERD) (Vendome Group LLC), 6(2), 27-42.

Goto, S., Gianfagia, T. J., Munafo, J. P., Fujii, E., Shen, X., Sun, M., ... Herrup, K. (2017). The power of traditional design techniques: the effects of viewing a Japanese garden on individuals with cognitive impairment. HERD: Health Environments Research \& Design Journal, 10(4), 74-86. https://doi.org/10.1177/1937586716680064.

Gould, E., \& Schieder, J. (2017). Work sick or lose pay?: The high cost of being sick when you don't get paid sick days (No. 130245). Retrieved from Economic Policy Institute website: https://www.epi.org/publication/work-sick-or-lose-pay-the-high-costof-being-sick-when-you-dont-get-paid-sick-days/.

Grazuleviciene, R., Danileviciute, A., Dedele, A., Vencloviene, J., Andrusaityte, S., Uždanaviciute, I., \& Nieuwenhuijsen, M. J. (2015). Surrounding greenness, proximity to city parks and pregnancy outcomes in Kaunas cohort study. International Journal of Hygiene and Environmental Health, 218(3), 358-365. https://doi.org/10.1016/j.ijheh.2015.02.004.

Grazuleviciene, R., Dedele, A., Danileviciute, A., Vencloviene, J., Grazulevicius, T., Andrusaityte, S., ... Nieuwenhuijsen, M. J. (2014). The Influence of Proximity to City Parks on Blood Pressure in Early Pregnancy. International Journal of Environmental Research and Public Health, 11(3), 2958-2972. https://doi.org/10.3390/ijerph110302958. 
Greed, C. (1996). Promise or progress: women in planning. Built Environment (1978-), 22(1), 9-21.

Greed, C. (2007). A place for everyone? Gender equality and urban planning. Retrieved from https://www.alnap.org/resource/6972.

Halsall, D. (2001). Transport and travel: better for women ? Geography, 86(1), 79-81.

Hankivsky, O. (2005). Gender vs Diversity Mainstreaming: A Preliminary Examination of the Role and Transformative Potential of Feminist Theory. Canadian Journal of Political Science / Revue Canadienne de Science Politique, 38, 977-1001.

Hargest-Slade, A. C., \& Gribble, K. D. (2015). Shaken but not broken: Supporting breastfeeding women after the 2011 Christchurch New Zealand earthquake. G Review, 23(3).

Hassan, Z. A. (2010, October 1). UN-HABITAT Awards City of Vienna for Excellence in Urban Planning. Retrieved April 3, 2018, from https://www.unis.unvienna.org/unis/pressrels/2010/uni sinf391.html.

Hegewisch, A., \& Williams-Baron, E. (2018). The Gender Wage Gap by Occupation 2017 (No. C467; p. 9). Retrieved from Institute for Women's Policy Research website: https://iwpr.org/wpcontent/uploads/2018/04/C467_2018-Occupational-Wage-Gap.pdf.

Hillin, T. (2016). Do ladies-only taxis and trains empower women - or set them back?

Hosseinpoor, A. R., Williams, J. S., Amin, A., de Carvalho, I. A., Beard, J., Boerma, T., ... Chatterji, S. (2012). Social determinants of self-reported health in women and men: Understanding the role of gender in population health. PLOS ONE, 7(4), e34799.

Japanese women can now travel in women-only train cars to avoid groping. (2006, August 21). Retrieved April 15, 2018, from Pravda Report website: https://www.pravdareport.com/news/soc iety/21-08-2006/84007-groping-0/.

Johnson, A. M., \& Miles, R. (2014). Toward more inclusive public spaces: Learning from the everyday experiences of Muslim Arab women in New York City. Environment and Planning A, 46(8), 1892-1907. https://doi.org/10.1068/a46292.

Kearl, H. (2018). The Facts behind the \#MeToo Movement: A National Study on Sexual Harassment and Assault (p. 41). Reston, Virginia: Stop Street Harassment.

Khazan, O. (2016). The Scourge of the Female Chore Burden.

Krasny, M. E., Pace, K. H., Tidball, K. G., \& Helphand, K. (2013). Nature Engagement to Foster Resilience in Military Communities. In Greening the Red Zone: Disaster, Resilience and Community Greening (p. 503). New York, London: Springer Dordrecht Heidelberg.

Kuo, F. E., \& Sullivan, W. C. (2001). Aggression and Violence in the Inner City: Effects of Environment via Mental Fatigue. Environment and Behavior, 33(4), 543-571. https://doi.org/10.1177/ 00139160121973124.

Lambrick, M., Viswanath, K., Husain, S., Blanes, P., Bozhkova, E., Dalmia, S. P., ... Whitzman, C. (2011). Tools for Gathering Information about Women's Safety and Inclusion in Cities (p. 64). Montréal, Canada: Women in Cities International.

Langohr, V. (2013). "This Is Our Square": Fighting Sexual Assault at Cairo Protests. Middle East Report, 268, 18-25.

Lorenzo, R., \& Reeves, M. (2018). How and Where Diversity Drives Financial Performance. Harvard Business Review Digital Articles, 2-5.

Loukaitou-Sideris, A., Bornstein, A., Fink, C., Samuels, L., \& Gerami, S. (2009). How to ease Women's Fear of Transportation Environments: Case Studies and Best Practices (pp. 96-96). Retrieved from Mineta Transportation Institute website: https://transweb.sjsu.edu/MTIportal/res earch/publications/documents/2611-women-transportation.pdf.

Madariaga, I. S. de. (2013a). From women in transport to gender in transport: challenging conceptual frameworks for improved policymaking. Journal of International Affairs, 67(1), 43-65.

Madariaga, I. S. de. (2013b). From women in transport to gender in transport: challenging conceptual frameworks for improved policymaking. Journal of International Affairs, 67(1), 43-65.

Markevych, I., Schoierer, J., Hartig, T., Chudnovsky, A., Hystad, P., Dzhambov, A. M., ... Fuertes, E. (2017). Exploring pathways linking greenspace to health: Theoretical and methodological guidance. Environmental Research, 158, 301-317. https://doi.org/10.1016/j.envres.2017.06.028. 
McEachan, R. R. C., Prady, S. L., Smith, G., Fairley, L., Cabieses, B., Gidlow, C., ... Nieuwenhuijsen, M. J. (2016). The association between green space and depressive symptoms in pregnant women: moderating roles of socioeconomic status and physical activity. J Epidemiol Community Health, 70(3), 253-259. https://doi.org/10.1136/jech-2015-205954.

Meagher Benjamin R. (2017). Judging the gender of the inanimate: Benevolent sexism and gender stereotypes guide impressions of physical objects. British Journal of Social Psychology, 56(3), 537-560. https://doi.org/10.1111/bjso.12198.

Micklow, A. C., \& Warner, M. E. (2014). Not Your Mother's Suburb: Remaking Communities for a More Diverse Population. Urban Lawyer, 46(4), 729-751. https://doi.org/10.1002/nbm.3369. Three.

Micklow, A., Kancilia, E., \& Warner, M. (2015). The need to plan for women: planning with a gender lens.

OECD. (2014). Balancing paid work, unpaid work, and leisure. Retrieved June 3, 2019, from OECD Better Policies for Better Lives: Gender Equality website: https://www.oecd.org/gender/data/bal ancingpaidworkunpaidworkandleisure.htm.

Okvat, H. A., \& Zautra, A. J. (2013). Sowing Seeds of Resilience: Community Gardening in a Post-Disaster Context. In Greening the Red Zone: Disaster, Resilience and Community Greening (p. 503). New York, London: Springer Dordrecht Heidelberg.

O’Reilly, M., Súilleabháin, A. Ó., \& Paffenholz, T. (2015). Reimagining Peacemaking: Women's Roles in Peace Processes (p. 42). Retrieved from International Peace Institute website: https:// www.ipinst.org/wp-content/uploads/2015/06/IPI-E-pub-Reimagining-Peacemaking.pdf.

Perera, G. (2008). Claiming the right to the city: A question of power. Right to the City Alliance, 15(1), 12-13.

Reid, L. W., \& Konrad, M. (2004). The Gender Gap in Fear: Assessing the Interactive Effects of Gender and Perceived Risk on Fear of Crime. Sociological Spectrum, 24(4), 399-425. https:// doi.org/10.1080/02732170490431331.

Rogers, R. (2014, February 17). Women are Kind and Men are Strong: How Benevolent Sexism Hurts Us All. Retrieved April 15, 2018, from https://www.themuse.com/advice/women-are-kindand-men-are-strong-how-benevolent-sexism-hurts-us-all.

Rollnick, R. (2007). The Global Assessment on Women's Safety (p. 85). Nairobi, Kenya: United Nations Human Settlements Programme.

Rondeau, M. B., Brantingham, P. L., \& Brantingham, P. J. (2005). The value of environmental criminology for the design professions of architecture, urban design, landscape architecture, and urban planning. Journal of Architectural and Planning Research, 22(4), 294-304.

Rustin, S. (2014, December). If women built cities, what would our urban landscape look like? The Guardian, 9-9.

Sham, R., Hamid, H. A., \& Noah, R. M. (2013). Routine Activities and Crime in the City: Cases of Working Women. Procedia - Social and Behavioral Sciences, 101, 345-353. https://doi.org/10. 1016/j.sbspro.2013.07.209.

Stafford M, Chandola T, \& Marmot M. (2007). Association between fear of crime and mental health and physical functioning. American Journal of Public Health, 97(11), 2076-2081. https://doi. org/10.2105/AJPH.2006.097154.

Stringer, S. M. (2007). Hidden in Plain Sight: Sexual Harassment and Assault in the New York City Subway System. 25.

Tandogan, O., \& Ilhan, B. S. (2016). Fear of Crime in Public Spaces: From the View of Women Living in Cities. Procedia Engineering, 161, 2011-2018. https://doi.org/10.1016/j.proeng.2016. 08.795 .

The American Institute of Architects. (2015). Diversity in the Profession of Architecture (p. 41). Retrieved from https://www.architecturalrecord.com/ext/resources/news/2016/03-Mar/AIA-Div ersity-Survey/AIA-Diversity-Architecture-Survey-02.pdf.

Tidball, K. G., \& Krasny, M. E. (Eds.). (2013). Greening in the Red Zone: Disaster, Resilience and Community Greening. New York, London: Springer Dordrecht Heidelberg.

U.N. Women. (2017). Safe cities and safe public spaces. 
UNDRR. (2019). Global Assessment Report on Disaster Risk Reduction (p. 472). Geneva, Switzerland: United Nations Office for Disaster Risk Reduction (UNDRR).

Urban Development Vienna. (2013). Gender Mainstreaming in Urban Planning and Urban Development (Workshop Report No. 130A; p. 104). Vienna: Municipal Department 18 - Urban Development and Planning.

van den Berg, M., van Poppel, M., van Kamp, I., Andrusaityte, S., Balseviciene, B., Cirach, M., ... Maas, J. (2016). Visiting green space is associated with mental health and vitality: A crosssectional study in four european cities. Health \& Place, 38, 8-15. https://doi.org/10.1016/j.hea lthplace.2016.01.003.

WHO Regional Office for Europe. (2016). Urban Green Spaces and Health: A Review of Evidence (p. 91). Retrieved from https://www.euro.who.int/en/health-topics/environment-and-health/ urban-health/publications/2016/urban-green-spaces-and-health-a-review-of-evidence-2016.

Wilson, J., Phillips, B. D., \& Neal, D. M. (1998). Domestic Violence After Disaster. In The Gendered Terrain of Disaster: Through Women's Eyes. (pp. 115-124). Westport, Connecticut: Praeger Publishers.

Wineman, J. D., Marans, R. W., Schulz, A. J., Westhuizen, D. L. van der, Mentz, G. B., \& Max, P. (2014). Designing Healthy Neighborhoods: Contributions of the Built Environment to Physical Activity in Detroit. Journal of Planning Education and Research, 34(2), 180-189. https://doi. org/10.1177/0739456X14531829.

Wisner, B., Blaikie, P., Cannon, T., \& Davis, I. (2003). At Risk: Natural Hazards, People's Vulnerability, and Disasters (2nd ed.). Retrieved from https://www.degruyter.com/view/j/jhsem.2005. 2.2/jhsem.2005.2.2.1131/jhsem.2005.2.2.1131.xml.

Women in Cities International. (2008). Women's safety audits: what works and where? (R. Rollnick, Ed.). Retrieved from www.unhabitat.org.

Women in Cities International. (2010). Learning from women to create gender inclusive cities: Baseline findings from the gender inclusive cities programme. 126-126.

Wood, L., Hooper, P., Foster, S., \& Bull, F. (2017). Public green spaces and positive mental health - investigating the relationship between access, quantity and types of parks and mental wellbeing. Health \& Place, 48, 63-71. https://doi.org/10.1016/j.healthplace.2017.09.002.

World Economic Forum. (2017). The global gender gap report: 2017. Geneva: World Economic Forum.

Open Access This chapter is licensed under the terms of the Creative Commons Attribution 4.0 International License (http://creativecommons.org/licenses/by/4.0/), which permits use, sharing, adaptation, distribution and reproduction in any medium or format, as long as you give appropriate credit to the original author(s) and the source, provide a link to the Creative Commons license and indicate if changes were made.

The images or other third party material in this chapter are included in the chapter's Creative Commons license, unless indicated otherwise in a credit line to the material. If material is not included in the chapter's Creative Commons license and your intended use is not permitted by statutory regulation or exceeds the permitted use, you will need to obtain permission directly from the copyright holder.

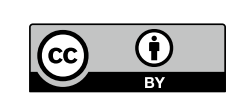

